\title{
RANCANG BANGUN SISTEM INFORMASI AKUNTANSI ARUS KAS PADA PT. ADHIYASTHA DHIWA INSANI
}

\author{
Paulus Mariano Alfonso Molo ${ }^{1}$ \\ Program Studi Sistem Informasi Akuntansi \\ Universitas Bina Sarana Informatika \\ paulusmariano@gmail.com \\ Barsilius Lucky Widiarsa ${ }^{2}$ \\ Program Studi Sistem Informasi Akuntansi \\ Universitas Bina Sarana Informatika \\ barsiliuslucky@gmail.com
}

\author{
Ahmad Al Kaafi ${ }^{3}$ \\ Program Studi Sistem Informasi Akuntansi \\ Universitas Bina Sarana Informatika \\ ahmad.akf@bsi.ac.id \\ Rusma Insan Nurachim ${ }^{4}$ \\ Program Studi Sistem Informasi Akuntansi \\ Universitas Bina Sarana Informatika \\ rusma.rsc@bsi.ac.id
}

\begin{abstract}
Abstrak - Arus kas merupakan bagian dari laporan keuangan yang disajikan untuk memberikan informasi terkait kondisi keuangan perusahan pada suatu periode tertentu serta berguna bagi berbagai pihak diantaranya manajemen, pihak eksternal serta bagi internal perusahan itu sendiri. PT. Adhiyastha Dhiwa Insani merupakan suatu usaha dagang yang bergerak di bidang perdagangan bahan pembangunan, proses pencatatan arus kas ditempat ini masih belum menggunakan sistem terkomputerisasi atau kata lain masih manual dalam pencatatan setiap transaksi yang terjadi yang dapat menyebabkan terjadinya kesalahan dalam pencatatan dan pengolahan data.

Rancang Bangun Sistem Informasi Akuntansi Arus Kas ini bertujuan untuk mengatasi masalah yang timbul dan mempermudah dalam pengolahan data serta pembuatan laporan pada PT. Adhiyastha Dhiwa Insani. Metode penelitian pengumpulan data yang dilakukan yaitu dengan cara observasi, wawancara dan studi pustaka sedangkan model pengembangan sistem yang digunakan adalah Waterfall Model, "Waterfall model sendiri adalah ranngkaian alur pengembangan sistem dimulai dari planning, analysis, design, implementation, operation \& maintenance".

Hasil dari penelitian ini adalah sebuah website perusahaan yang dapat mempermudah pengelolaan data dan pembuatan laporan arus kas sehingga pekerjaan yang dilakukan lebih efisien.

Kata Kunci: Sistem Informasi, Website, Arus Kas, Waterfall
\end{abstract}

\section{Pendahuluan}

\section{A. Latar Belakang}

Perkembangan teknologi informasi tidak terlepas dari komputer. Komputer sebagai salah satu unsur dari teknologi informasi merupakan alat yang bisa meningkatkan kemampuan manusia dalam proses pengerjaannya. Akhirnya banyak perusahaan-perusahaan yang berskala besar, menengah maupun kecil menggunakan komputer untuk mendukung kegiatan yang dilakukan dalam usahanya. Dapat disimpulkan penggunaan teknologi informasi dibutuhkan dalam pembuatan laporan keuangan yang efektif.

Arus kas merupakan bagian dari laporan keuangan yang disajikan untuk memberikan informasi terkait kondisi keuangan perusahaan pada suatu periode tertentu serta berguna bagi berbagai pihak diantaranya manajemen, pihak eksternal dan internal perusahan itu sendiri.

PT. Adhiyastha Dhiwa Insani merupakan suatu usaha dagang yang bergerak di bidang perdagangan bahan pembangunan, proses pencatatan arus kas ditempat ini menggunakan sistem manual dalam pencatatan setiap transaksi yang terjadi. Sehingga menyebabkan terjadinya kesalahan dalam pencatatan dan pengolahan data karena sering terjadinya dua kali pencatatan atau tidak tercatat dan penumpukan dokumen-dokumen transaksi penerimaan kas dan pengeluaran kas yang membuat pegawai harus mencari dan membuka satu persatu dokumen sehingga menghambat kerja pegawai, sehingga sistem arus kas usaha dagang ini bisa dikatakan masih belum efektif.

\section{B. Metode Pengembangan Software}

Model pengembangan sistem yang digunakan oleh penulis adalah Waterfall Model, "Waterfall model sendiri adalah ranngkaian alur pengembangan sistem dimulai dari planning, analysis, design, implementation, operation \& maintenance." Seperti yang dikatakan A.S Rosa dan Shalahuddin dalam (Astuti, Fauziah, 
Yudistira, \& Noviriandini, 2019) berikut adalah tahapan-tahapan metode waterfall :

1. Analisis kebutuhan perangkat Lunak

Proses pengumpulan kebutuhan dilakukan secara intensif untuk menspesifikasikan kebutuhan perangkat lunak, agar dapat dipahami perangkat lunak seperti apa yang dibutuhkan oleh user. Spesifikasi kebutuhan perangkat lunak pada tahap ini perlu untuk didokumentasikan.

\section{Desain}

Proses ini fokus pada desain pembuatan sistem pencatatan arus kas. Perancangan dimulai dari tahap UML (Unified Modelling Language) diagram yang digunakan adalah Activity Diagram, Use Case Diagram, Sequence Diagram dan Deployment Diagram, dilanjutkan merancang database menggunakan Entity Relationship Diagram (ERD) dan Logical Record Structure (LRS), Spesifikasi File dan User Interface.

3. Pembuatan kode program

Desain harus ditranslasikan ke dalam program perangkat lunak. Hasil dari tahap ini adalah program komputer sesuai dengan desain yang telah dibuat pada tahap desain.

4. Pengujian

Proses pengujian program menggunakan blackbox testing untuk meminimalisir kesalahan (error) dan memastikan keluaran yang dihasilkan sesuai dengan yang diinginkan.

5. Pendukung

Support dapat berupa pemeliharaan (Maintenance) yang dilakukan dengan cara-cara sederhana seperti: memasang anti-virus di komputer, memberikan pengarahan kepada user untuk selalu back up data yang penting, setidaknya sebulan sekali melakukan defragment, menyisakan sedikit space kosong di partisi sistem operasi disimpan, melakukan pengecekan virus secara rutin dan jangan pernah mematikan power hingga sistem benar-benar telah shutdown.

\section{Landasan Teori}

\subsubsection{Sistem Informasi Akuntansi}

Menurut (Laudon, 2015) Sistem Informasi Akuntansi adalah komponen- komponen yang saling berhubungan dan bekerja sama untuk mengumpulkan, memproses, menyimpan informasi untuk mendukung pengambilan keputusan koordinasi, pengendalian, dan untuk memberikan gambaran aktivitas didalam perusahaan.

Sedangkan menurut (Mahatmyo, 2014) "Sistem informasi akuntansi merupakan sekelompok struktur dalam sebuah entitas yang mengelola sumber daya fisik dan sumber daya lain untuk mengubah data ekonomi menjadi informasi akuntansi, agar dapat memenuhi kebutuhan informasi berbagai pihak".

Maka dapat disimpulkan bahwa sistem informasi akuntansi adalah komponen - komponen yang saling berhubungan dan bekerja sama untuk mengumpulkan dan mengolah sumber daya fisik dan sumber daya lain untuk mengubah data ekonomi menjadi informasi akuntansi, yang dapat memenuhi informasi dari berbagai pihak.

A. Unsur - unsur Sistem Informasi Akuntansi

Unsur suatu sistem informasi akuntansi pokok menurut Mulyadi dalam (Astuti et al., 2019) adalah:

1. Formulir

Merupakan dokumen yang digunakan untuk merekam terjadinya transaksi. Formulir sering disebut dengan istilah dokumen, karena dengan formulir ini peristiwa yang terjadi dalam organisasi dapat direkam (didokumentasikan) diatas secarik kertas.

2. Jurnal

Jurnal yaitu catatan akuntansi pertama yang digunakan untuk mencatat, mengklasifikasikan dan meringkas data keuangan dan data lainya. Dalam jurnal ini terdapat peringkasan data, yang hasil peringkasannya (berupa jumlah rupiah transaksi tertentu) kemudian dicatat ke akun yang terkait dalam buku besar.

3. Buku Besar

Buku Besar terdiri dari rekening-rekening yang digunakan untuk meringkas data keuangan yang telah dicatat sebelumnya kedalam jurnal.

4. Buku Pembantu

Buku pembantu terdiri dari rekening-rekening pembantu yang merinci data keuangan yang tercantum dalam rekening keuangan tertentu dalam buku besar.

5. Laporan

Laporan berisi informasi yang merupakan keluaran (output) sistem akuntansi. Laporan keuangan berupa laporan posisi keuangan, laporan laba rugi, laporan perubahan saldo laba, laporan harga pokok produksi, laporan beban pemasaran, laporan beban pokok penjualan, daftar umur piutang, daftar utang yang akan dibayar dan daftar saldo persediaan yang lambat penjualannya.

\subsection{Unified modelling Language (UML)}

Menurut A.S Rosa dan Salahudin dalam (Fridayanthie \& Mihdiati, 2016) "UML (Unified Modeling Language) adalah salah satu standar bahasa yang banyak digunakan di dunia industri untuk medefinisikan requirement, membuat analisis dan desain, serta menggambarkan arstitektur dalam pemograman berorientasi objek". Sedangkan menurut Gata dalam (Hendini, 
2016) Unified Modeling Language (UML) adalah bahasa spesifikasi standar yang dipergunakan untuk mendokumentasikan, menspesifikasikan dan membanngun perangkat lunak. UML merupakan metodologi dalam mengembangkan sistem berorientasi objek dan juga merupakan alat untuk mendukung pengembangan sistem.

Maka dapat disimpulkan UML adalah salah satu standar dari bahasa spesifikasi yang digunakan untuk pemograman berorientasi objek dan juga alat untuk pengembangan sistemnya.

Alat bantu yang digunakan dalam perancangan $U M L$ sebagai berikut:

\section{Diagram Activity}

Menurut (A.S Rosa \& Salahudin, 2014) "Diagram aktivitas atau activity diagram menggambarkan workflow (aliran kerja) atau aktivitas dari sebuah sistem atau proses bisnis atau menu yang ada pada perangkat lunak".

\section{Use Case Diagram}

Menurut (A.S Rosa \& Salahudin, 2014) "Use case atau diagram use case merupakan pemodelan untuk kelakuan (behavior) sistem informasi."

\section{Class Diagram}

Menurut (Hendini, 2016) "Merupakan hubungan antar kelas dan penjelasan detail tiap-tiap kelas di dalam model desain dari suatu sistem, juga memperlihatkan aturan-aturan dan tanggung jawab entitas yang menentukan perilaku sistem".

\section{Squence Diagram}

Menurut (Hendini, 2016) "Sequence Diagram menggambarkan kelakuan objek pada use case dengan mendeskripsikan waktu hidup objek dan pesan yang dikirimkan dan diterima antara objek".

\section{Deployment Diagram}

Menurut (Hendini, 2016) "Deployment Diagram digunakan untuk gambaran detail bagaimana komponen disusun di infrastruktur sistem".

\section{Analisa Kebutuhan Bisnis}

Setelah menganalisa Sistem Informasi secara langsung pada PT. Adhiyastha Dhiwa Insani penulis menemukan permasalah-permasalahan yang terjadi, yaitu disebabkan karena :

1. Pencatatan laporan yang dibuat tidak akurat untuk setiap bulannya, sehingga pemilik tidak mengetahui laporan keuangan yang menjadi perbandingan setiap bulannya.

2. Penyimpanan dokumen-dokumen yang di arsipkan masih sederhana sehingga dokumen sering terjadi kehilangan dan kerusakan.

Berdasarkan permasalahan diatas penulis menyimpulkan alternatif pemecahan masalah diantaranya:

1. Usulan untuk PT. Adhiyastha Dhiwa Insani dibuatkan sebuah sistem informasi akuntansi berupa website, dimana pegawai dapat memasukkan data transaksi dan menghasilkan laporan sesuai transaksi.

2. Dengan adanya sistem usulan ini maka setiap dokumen yang ada dapat di input kedalam database untuk di arsipkan sehingga terhindar dari hilang dan kerusakan pada dokumen serta memudahkan dalam pencarian data.

\section{Usulan Penelitian}

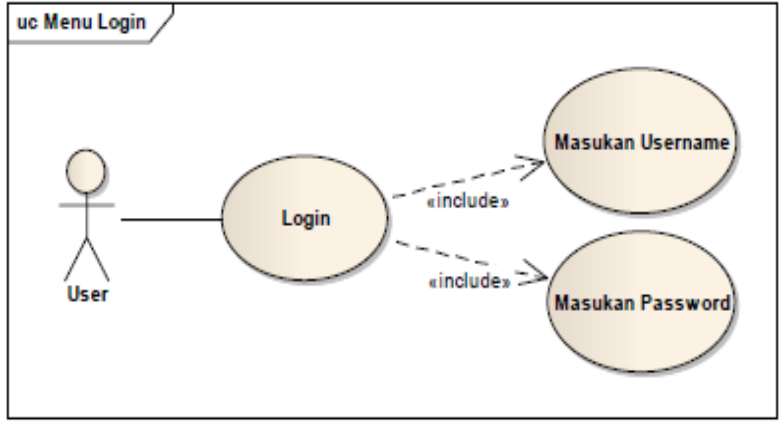

4.1 Use Case Diagram

A. Use case diagram Login User

Gambar IV.1

Use Case Diagram Login User

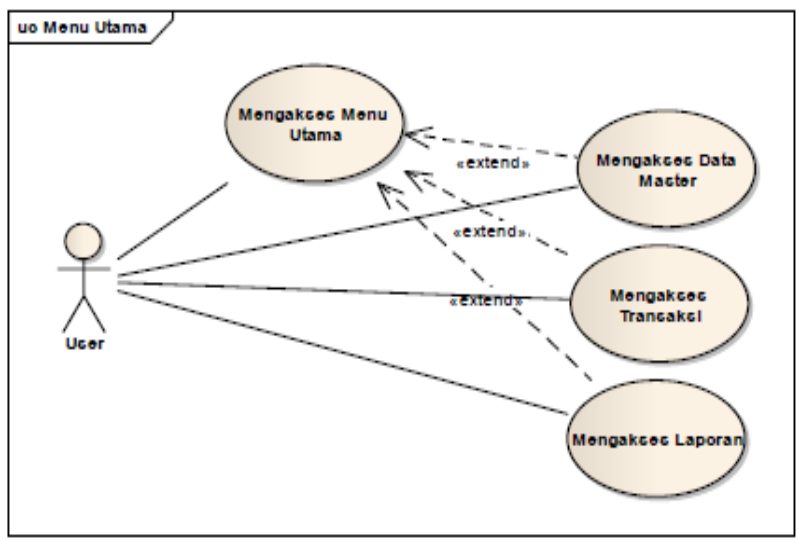

B. Use case diagram User menu utama user

Gambar IV.2

Use Case Diagram Menu Utama User

C. Use case diagram User menu Master Data 


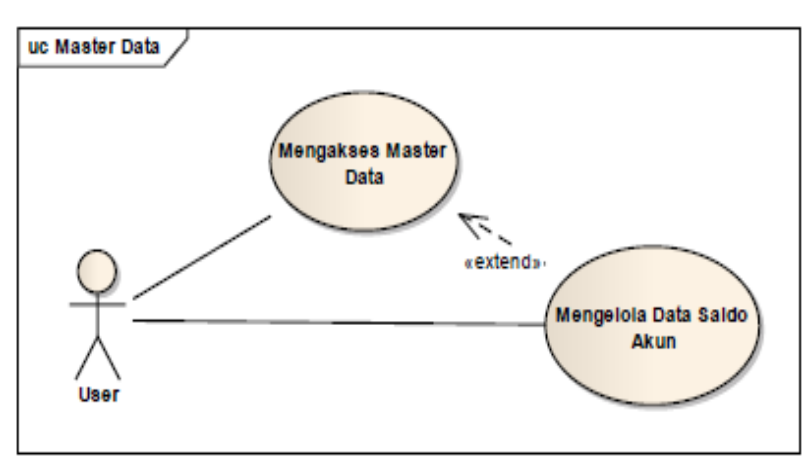

Gambar IV.3

Use Case Diagram Menu Master Data

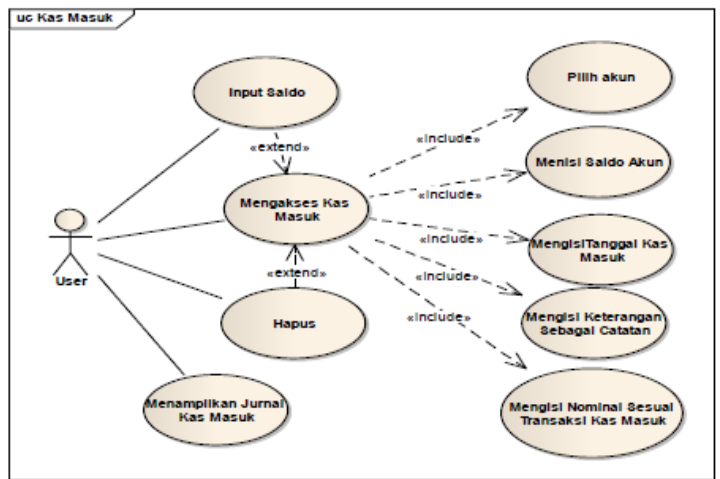

Gambar IV.6

Use Case Diagram Menu Data Kas Masuk
D. Use case diagram User menu Data Saldo Akun

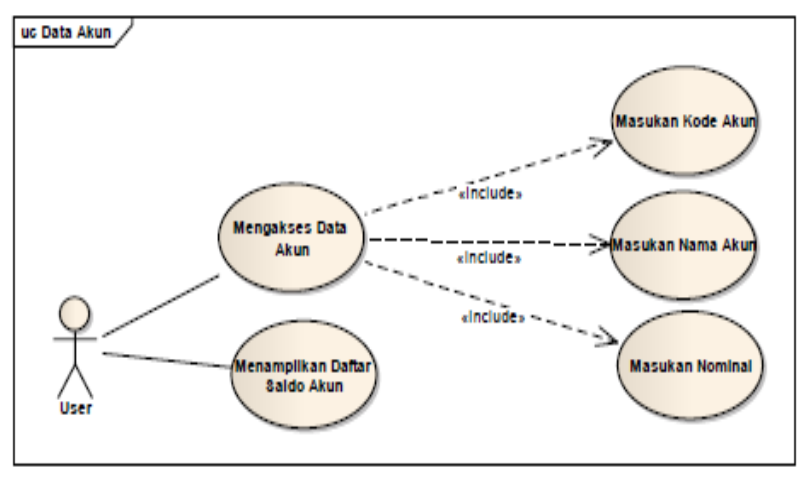

Gambar IV.4

Use Case Diagram Menu Data Saldo Akun

E. Use case diagram User menu Transaksi

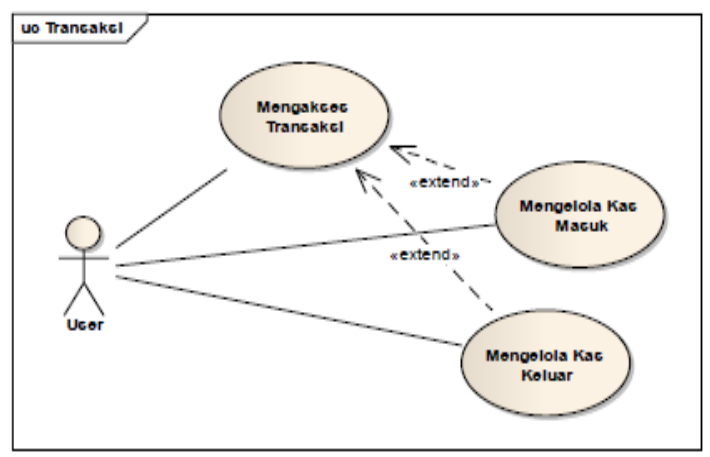

Gambar IV.5

Use Case Diagram Menu Transaksi

F. Use case diagram User menu Data Kas Masuk
G. Use case diagram User menu Data Kas Keluar

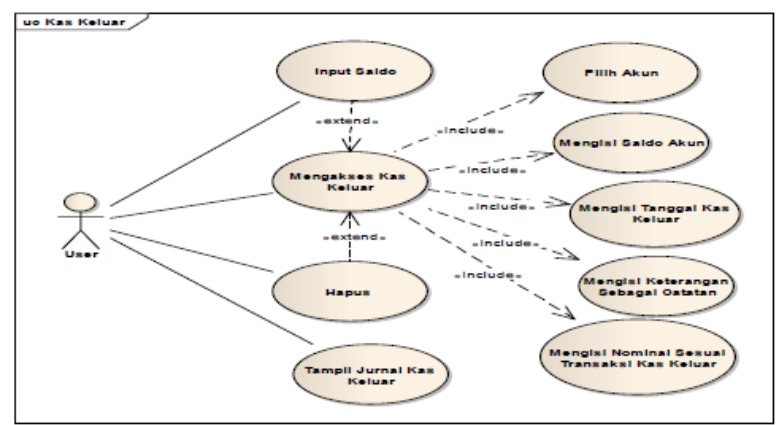

Gambar IV.7

Use Case Diagram Menu Data Kas Keluar

H. Use case diagram User menu Laporan

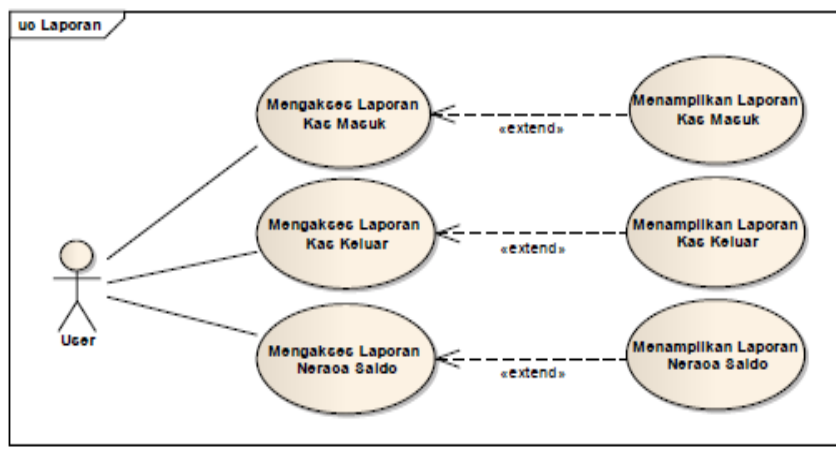

Gambar IV.8

Use Case Diagram Menu Laporan

I. Use case diagram login Admin 


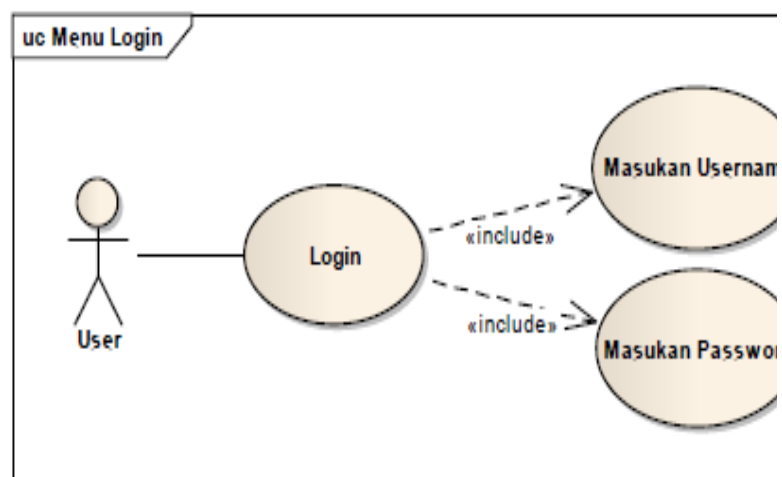

Gambar IV.9

Use Case Diagram Menu Login Admin

\subsection{Activity Diagram}

A. Activity Diagram Menu Utama

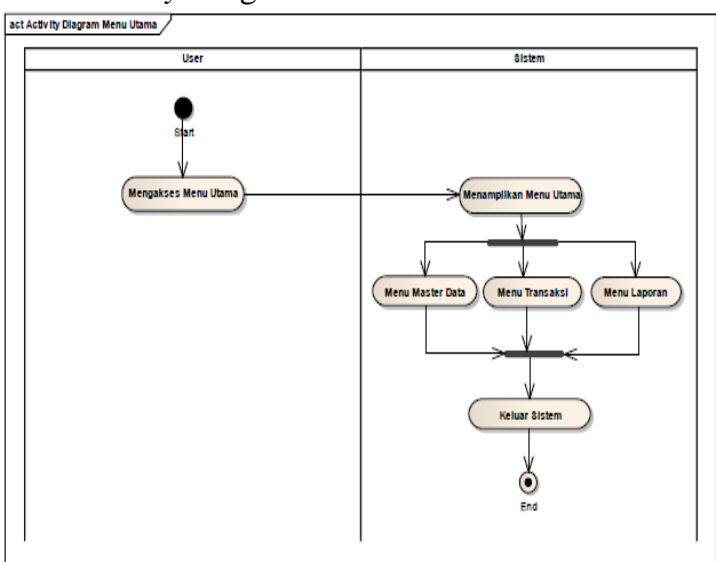

Gambar IV.12

Activity Diagram Menu Utama

B. Activity Diagram Data Saldo Akun

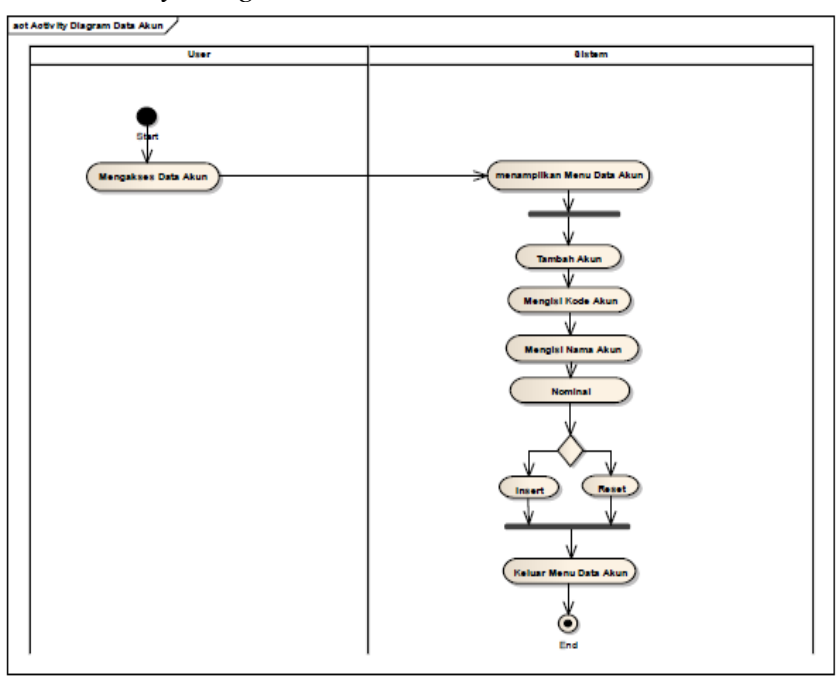

Gambar IV.13

Activity Diagram Data Saldo Akun

C. Activity Diagram Data Kas Masuk

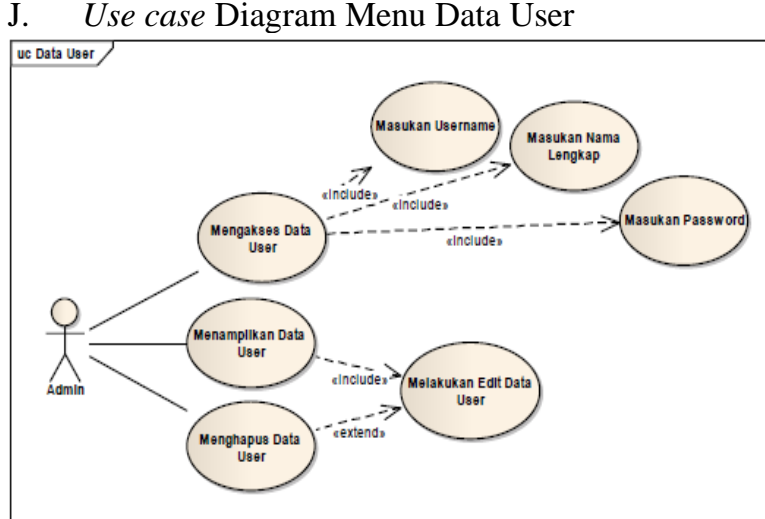

Gambar IV.10

Use Case Diagram Menu Data User

K. Use Case Diagram Menu Laporan

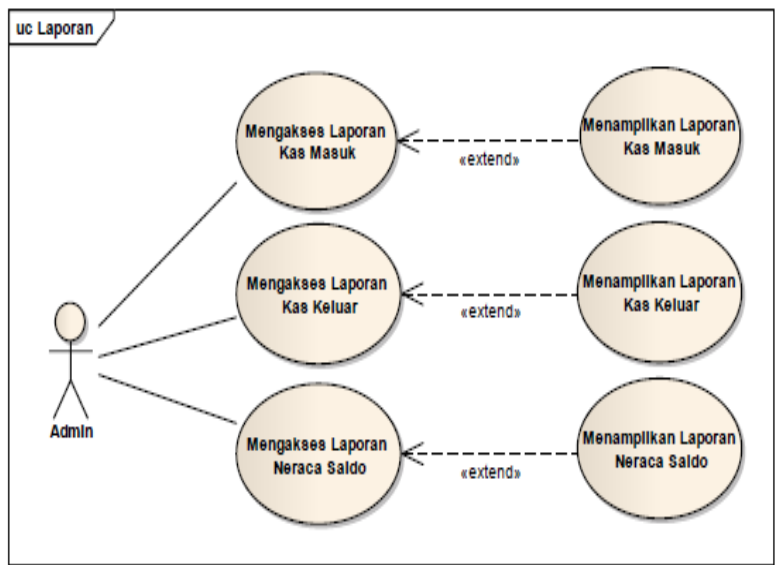

Gambar IV.11

Use Case Diagram Menu Data Laporan 


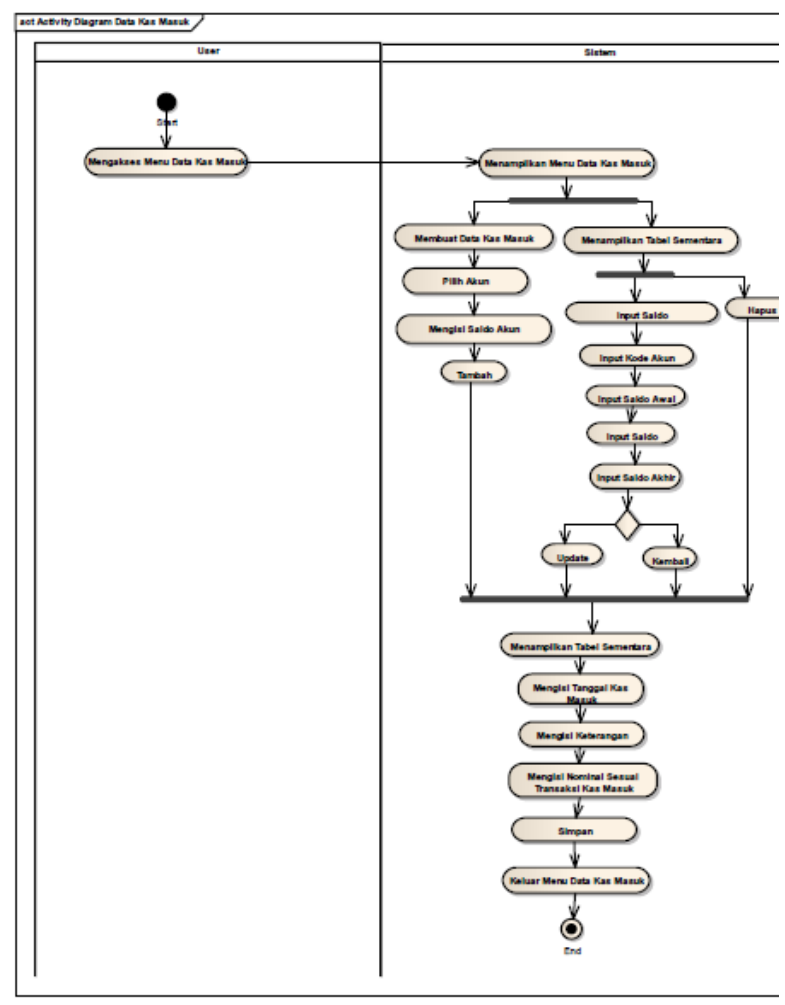

Gambar IV.14

Activity Diagram Data Kas Masuk

D. Activity Diagram Data Kas Keluar

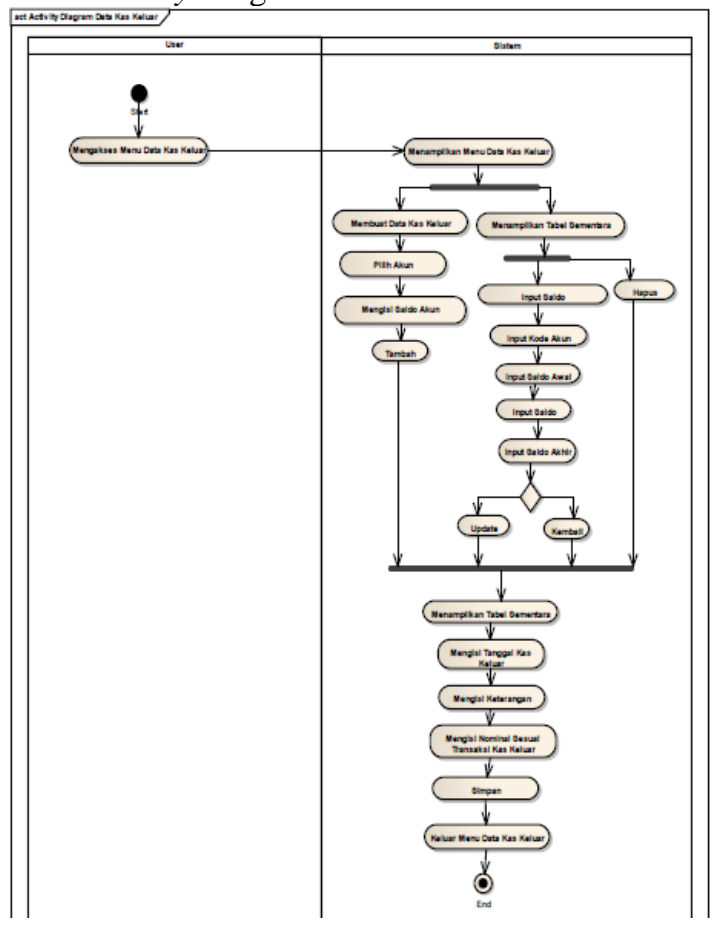

Gambar IV.15

Activity Diagram Data Kas Keluar
$4.3 \quad$ ERD

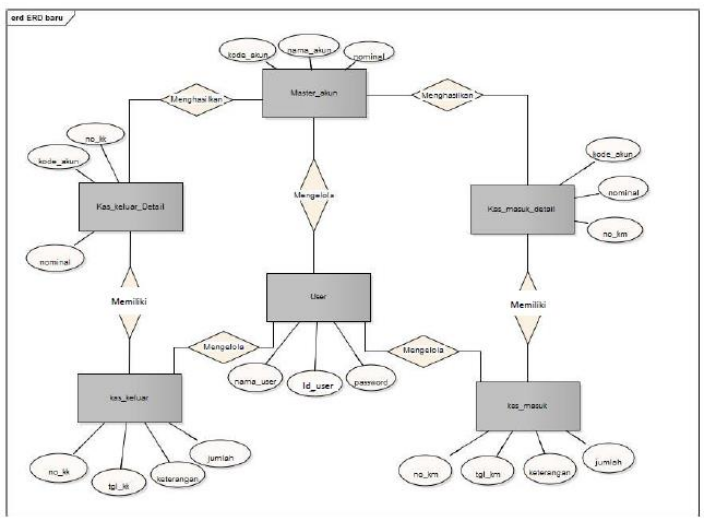

Gambar IV.16

Entity Relationship Diagram

4.4 LRS

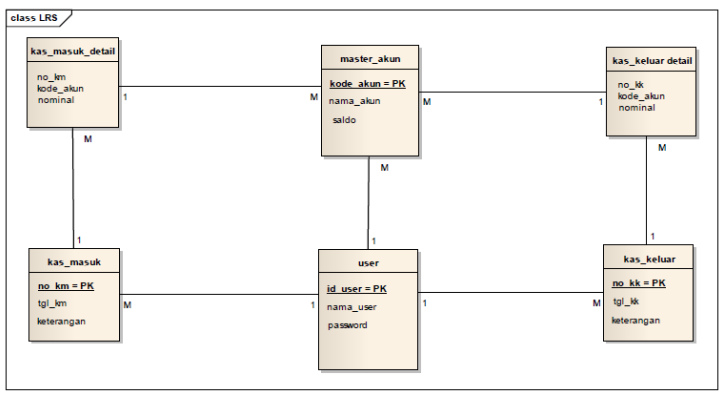

Gambar IV.17

Logical Record Structure

\subsection{Deployment Diagram}

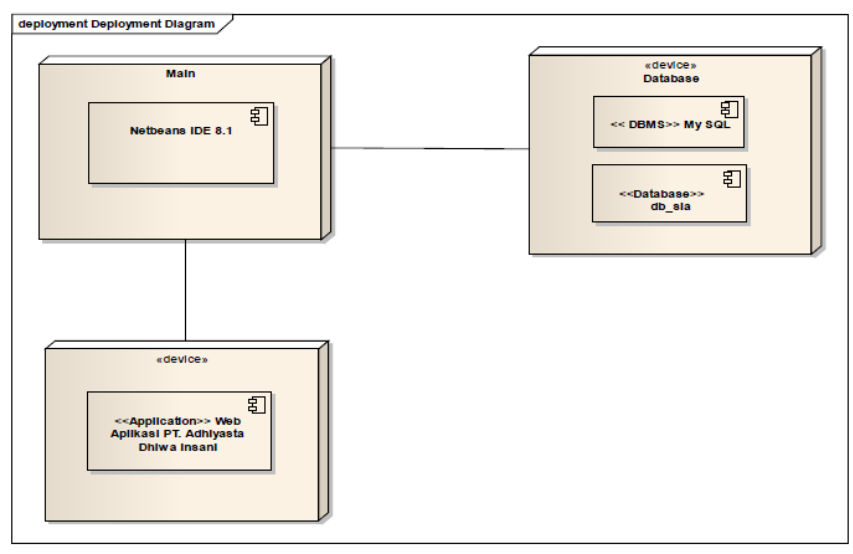

Gambar IV.18

Deployment Diagram 
4.6 User Interface

A. Login User

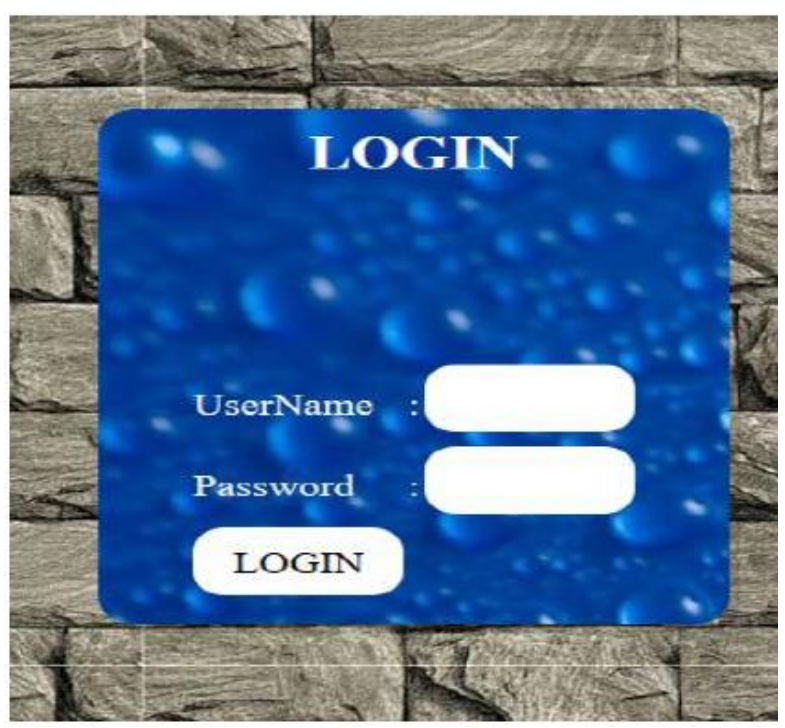

Gambar IV.19

Tampilan Halaman Login User

B. Menu Utama User

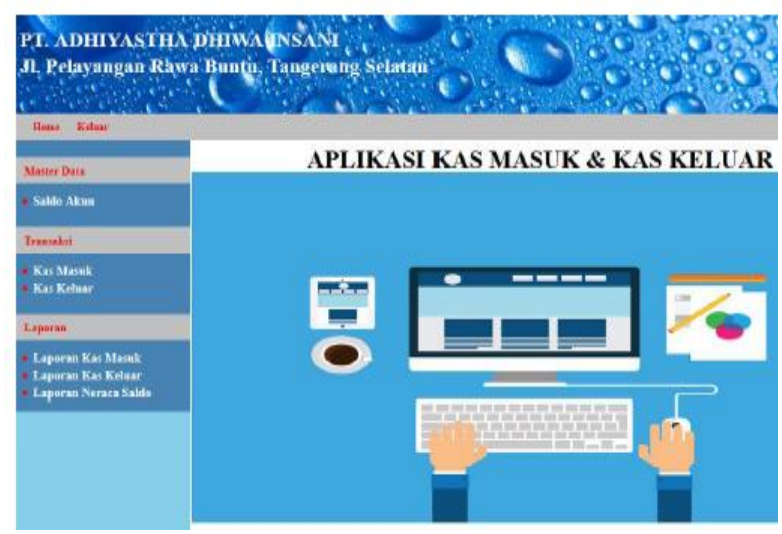

Gambar IV.20

Tampilan Menu Utama User

C. Data Saldo Akun

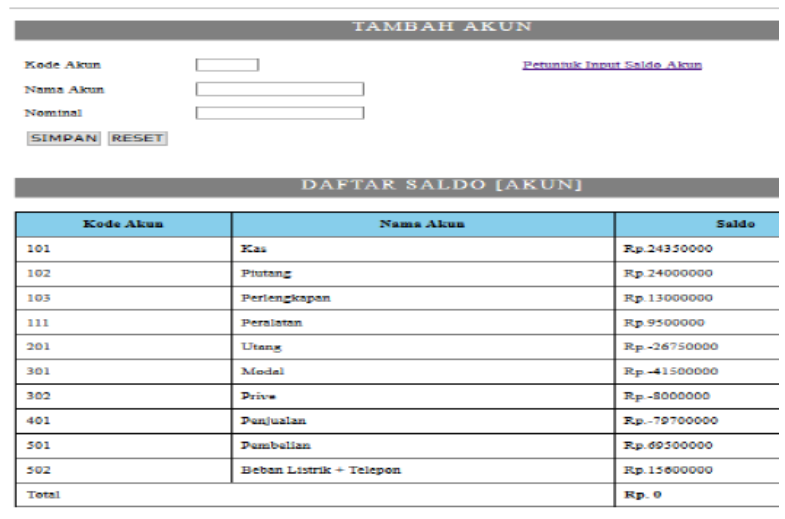

Tampilan Data Saldo Akun

D. Data Kas Masuk

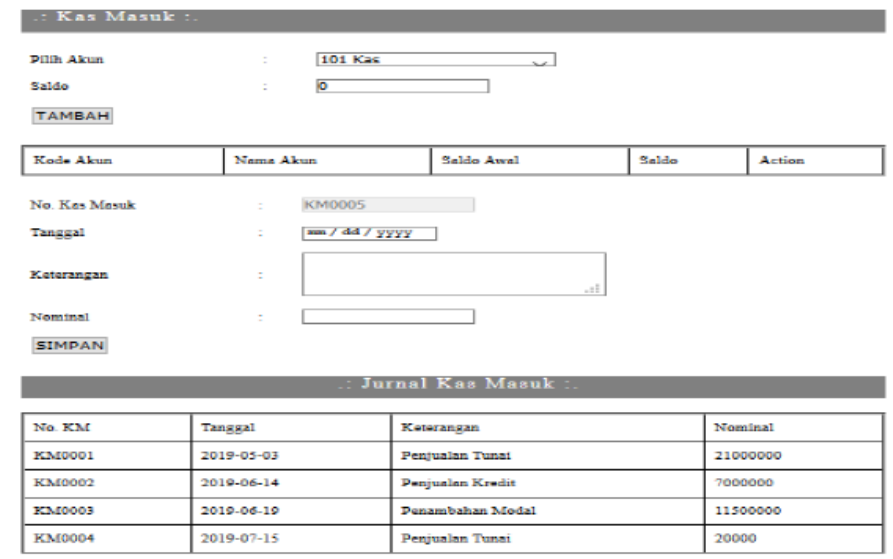

Gambar IV.22

Tampilan Data Kas Masuk

E. Data Kas Keluar

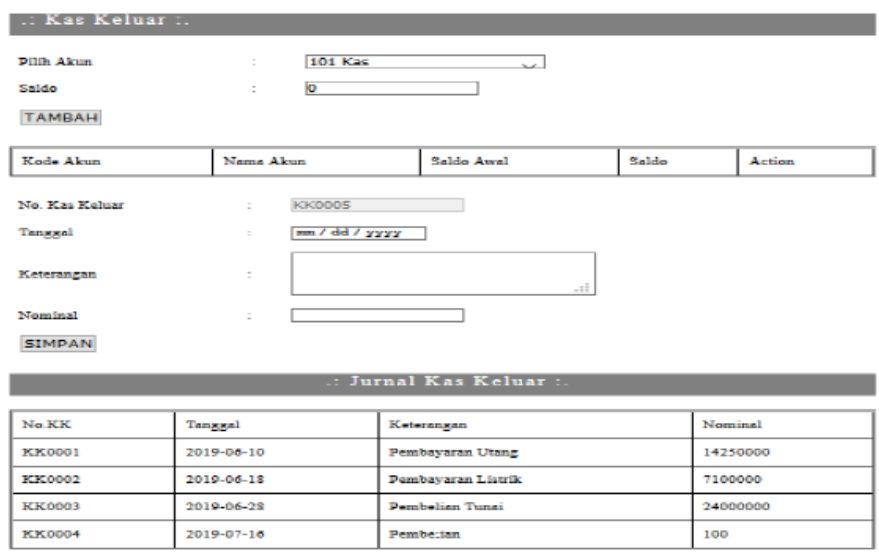

Gambar IV.23

Tampilan Data Kas Keluar

Gambar IV.21 
F. Halaman Utama Admin

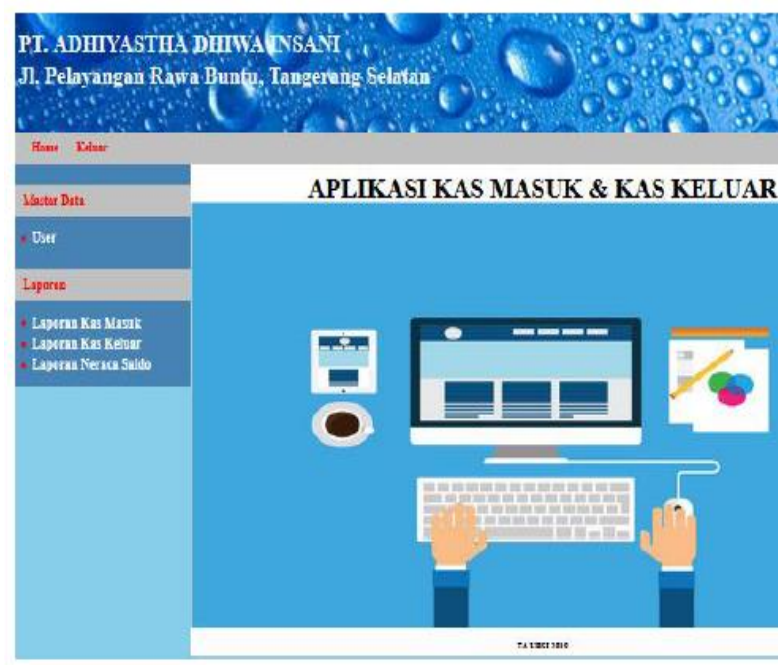

Gambar IV.24

Tampilan Halaman Utama Admin

G. Halaman Menu data User

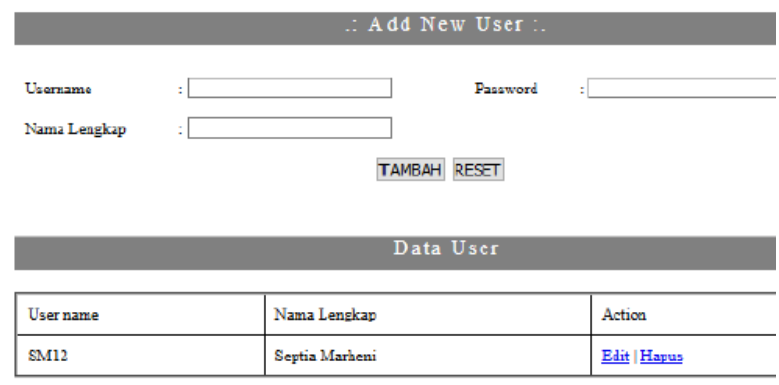

Gambar IV.25

Tampilan Halaman Data User

\section{Kesimpulan dan Saran}

5.1 Kesimpulan

Berdasarkan hasil pengamatan sistem informasi arus kas pada PT. Adhiyastha Dhiwa Insani yang telah dilaksanakan maka dapat disimpulkan bahwa:

1. Sistem yang belum terkomputerisasi membuat kurang efektifnya proses pengumpulan dokumen transaksi dan pengarsipan. Banyak terjadi kesalahan penulisan dalam laporan penerimaan dan pengeluaran kas. Penyimpanan dokumen-dokumen transaksi memiliki resiko kehilangan.

2. Dengan sistem yang sudah terkomputerisasi proses pengolahan data menjadi lebih efektif. Karena semua data tersimpan dalam sistem dan mudah diakses jika diperlukan.

\subsection{Saran}

Dari kesimpulan diatas penulis memberikan saran dalam menjalankan sistem informasi akuntansi sebagai berikut :

1. Agar sistem yang telah terkomputerisasi dapat berjalan dengan baik, perlu adanya dukungan sumber daya manusia yang dapat menjalankan sistem tersebut maka diperlukan pelatihan kepada user agar dapat mengoperasikan program dengan efektif.

2. Perlu adanya perawatan sistem secara berkala dan dibuatkan password dan hak akess agar tidak semua pengguna user atau karyawan dapat mengakses sistem tersebut.

3. Evaluasi program secara berkala, agar dapat dikembangkan sesuai kebutuhan perusahaan.

\section{Daftar Pustaka}

A.S Rosa, \& Salahudin. (2014). Rekayasa Perangkat Lunak Terstruktur dan Berorientasi Objek. Bandung: Informatika

Agus, P., \& Safitri, Y. (2015). Pemanfaatan Sistem Informasi Perpustakaan Digital Berbasis Website Untuk Para Penulis Agus Prayitno 1) Yulia Safitri 2). Indonesian Journal on Software Engineering, 1(1), 1-10

Agustini, F. (2017). Sistem Informasi Penyewaan Kamar Menggunakan Metode Waterfall Dengan Konsep Pemrograman Berbasis Objek ( Studi Kasus: Hotel Bonita Cisarua Bogor ). Teknik Komputer AMIK BSI, III(1), 114-123.

Candra, Siregar, \& Rukiastiandari. (2019). APLIKASI PENDAFTARAN PASIEN RAWAT JALAN RUMAH SAKIT MEILIA CIBUBUR BERBASIS WEB. 1-10

Fridayanthie, \& Mihdiati. (2016). Rancang Bangun Sistem Informasi Permintaan ATK Berbasis Internet. Jurnal Khatulistiwa Informatika2, 4(2), 126-138.

Hendini. (2016). PEMODELAN UML SISTEM INFORMASI MONITORING PENJUALAN DAN STOK BARANG (STUDI KASUS: DISTRO ZHEZHA PONTIANAK). Jurnal Khatulistiwa Informatika, 4, 107-116.

Hery. (2015). Akuntansi Dasar 1 \& 2. Jakarta: PT.Grasindo. Hutahean. (2014). Konsep Sistem Informasi. Yogyakarta: Deepublish.

Laudon. (2015). Sistem Informasi Manajemen (10th ed.; C. Sungkono, ed.). Jakarta Selatan: Salemba Empat. 
Mahatmyo. (2014). Sistem Informasi Akuntansi Suatu Pengantar (1st ed.). Yogyakarta: Deepublish.

Supriyanta, \& Suparlan. (2017). Perancangan Sistem Informasi Penjualan Pakaian Pada Alea Zahra Shop Yogyakarta. Jurnal Bianglala Irformatika, 5, 32-36.

Sutabri. (2016). Sistem Informasi Manajemen (Revisi). Yogyakarta: CV.Andi Offiset.

Wehantouw, A. B., \& Tinangon, J. J. (2015). ANALISIS LAPORAN ARUS KAS

OPERASI, INVESTASI DAN PENDANAAN PADA PT. GUDANG GARAM TBK. Jurnal EMBA, 3, 806-817. 